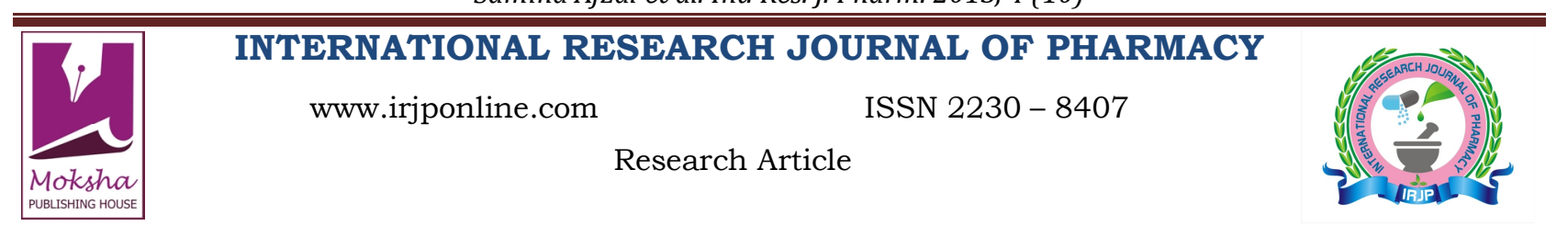

\title{
ISOLATION OF PENTANDRAONE FROM METHANOLIC EXTRACT OF AERIAL PART OF ZALEYA PENTANDRA
}

Samina Afzal ${ }^{1}$, Bashir Ahmad Chaudhary ${ }^{1}$, Muhammad Uzair ${ }^{1}$, Khurram Afzal ${ }^{2}$, Tasveer Zahra Bokhari ${ }^{3}$

${ }^{1}$ Faculty of Pharmacy, Bahauddin Zakariya University, Multan- Pakistan

${ }^{2}$ Ph.D. Scholar Bahauddin Zakariya University, Multan- Pakistan

${ }^{3}$ Institute of Biology, Bahauddin Zakariya University, Multan- Pakistan

*Corresponding Author Email: tzb_5@hotmail.com

Article Received on: 20/08/13 Revised on: 07/09/13 Approved for publication: 12/09/13

DOI: $10.7897 / 2230-8407.041006$

IRJP is an official publication of Moksha Publishing House. Website: www.mokshaph.com

(C) All rights reserved.

\section{ABSTRACT}

Zaleya pentandra is a well known species in the genus Zaleya. It has wide traditional medicinal uses. Zaleya pentandra is being used for treatment of stomach diseases, respiratory tract infection and cough. For the purpose of isolation from the dried aerial parts of Zaleya pentandra was subjected to extraction with methanol, this combined extract was concentrated and column chromatography was then carried out. The isolation and purification yielded amorphous solid which was subjected to physical, chemical, and spectral techniques like UV, IR, ${ }^{1} \mathrm{H}-\mathrm{NMR}$, ${ }^{13} \mathrm{C}-\mathrm{NMR}$ and $\mathrm{HREI}-\mathrm{MS}$ for the structure elucidation of compound. The compound was concluded as pentandraone, a novel compound isolated for the first time from the methanolic extract of aerial part of Zaleya pentandra.

Keywords: Zaleya pentandra, Column chromatography, Extraction, Pentandraone

\section{INTRODUCTION}

Zaleya pentandra, which belongs to family Aizoaceae, has about 1170 species and 128 genera, many of which are cultivated in tropical Africa, South America, West India, Mediterranean and tropical Asia. Zaleya is widely distributed prostrate and branched herbs. A genus of about 6 species found in Africa, Asia and Australia, only one species, Zaleya pentandra, found in Pakistan ${ }^{1}$. The genus is enriched with pharmacological properties. Trianthema decandra showed hepatoprotective ${ }^{2}$, antidiabetic activity ${ }^{3}$, antioxidant activity ${ }^{4}$, antibacterial activity, antimicrobial activity ${ }^{6}$, antipyretic, analgesic and anti-inflammatory activity ${ }^{7}$. Trianthema Portulacastrum also displayed hepatoprotective activity, anti-cancer property ${ }^{9}$, hypoglycemic, anti-hyperglycemic and hypolimidemic ${ }^{10}$, anthelmintic activity ${ }^{11}$ antifungal activity and use in renal disorder ${ }^{12}$. Literature survey of genus revealed phytochemical constituent Trianthemine, Trianthenol and Ecdysteroid reported from chloroform extract of Zaleya portulacastrum ${ }^{13,14}$ along with Flavonoids and phytoserolines and Ketone ${ }^{15}$. Many species of this genus have been reported to act as folk medicine for treating bronchial diseases, cathartic, irritant, fever, constipation, urinary tract infection as well as dissolve the kidney and bladder stone. The Zaleya portulacastrum is being used to decrease the size distribution, incidence and multiplicity of all the apparent cancerous cells. It can also be used as a cathartic, irritant, diuretic and also break the kidney and bladder stone ${ }^{16}$. The plant Zaleya pentandra is used as an astringent in snake bite and as a fodder for cattle. It's also used for malaria ${ }^{17}$. Zaleya pentandra is being used for stomach diseases ${ }^{18}$, respiratory tract infection and cough ${ }^{19}$. The genus Zaleya has diverse medicinal application that motivated us to carry out the phytochemical investigations on this species. Herein we submit the report about the isolation and characterization of a novel steroid hormone named as Pentandraone.

\section{MATERIALS AND METHODS}

General

Column chromatography has been used for the purpose of isolation with silica gel of 70-230, 230-400 mesh along with sephadex LH-20. For TLC purpose, aluminum sheets precoated silica gel $60 \mathrm{~F}_{254}(20 \times 20 \mathrm{~cm}, 0.2 \mathrm{~mm}$ thick; EMerck) have been used to check the percentage purity of the compounds. The visualization of components was observed under ultraviolet light ( 254 and $366 \mathrm{~nm}$ ) followed by Godine reagent and $10 \%$ sulphuric acid were used as spraying reagent. IR spectrum was recorded by using Bruker vector200 spectrophotometer $\left(v\right.$ in $\left.\mathrm{cm}^{-1}\right)$. EI-MS spectrum was recorded on Jeol JMS-600H spectrometer and HREI-MS was recorded on MET-95-XP. The ${ }^{1} \mathrm{H}-\mathrm{NMR}$ spectrum was recorded by Bruker Avon- $300 \mathrm{MHz}$ instruments by using TMS as internal standard. The values of chemical shift were reported in ppm $(\delta)$ units and the coupling constants $(\mathrm{J})$ they were recorded in $\mathrm{Hz}$. The ${ }^{13} \mathrm{C}-\mathrm{NMR}$ spectrum was also recorded on Bruker Avon-300 MHz instruments.

\section{Plant collection}

The whole plant of Zaleya Pentandra was collected from Peruwal (District Khanewal) and identified by Professor Dr. Altaf Ahmed Dasti, plant Taxonomist, Institute of pure and applied biology, Bahauddin Zakariya University, Multan, Pakistan; whereas voucher specimen fl. P.235/5 for Zaleya pentandra was deposited.

\section{Isolation}

The freshly collected whole plant material of Zaleya Pentandra (1000 g) was shade dried ground and extracted successively with methanol $(3 \times 6 \mathrm{~L})$ at room temperature for 24 hours. The combined methanolic extract was concentrated under vacuum on Rota vapor model no. Buchi-rotavapor R.200 to yield dark brown crude extracts (35 g) which was labeled as ZPM. The methanolic extract (35 g) was then fractioned with column chromatography over silica gel using step wise elution with chloroform : methanol : $\mathrm{H}_{2} \mathrm{O}(80: 20$ : 2 ) by increasing the polarity of mobile phase-Five fractions 
Samina Afzal et al. Int. Res. J. Pharm. 2013, 4 (10)

(1-5) were obtained. The fraction 3 (245 $\mathrm{mg})$ from extract of Zaleya pentandra was further fractionated by using column chromatography where mixture of Chloroform: methanol: water. (85: 15: 1) was used as eluent. Nine fractions were obtained. The analysis of fraction 5 affords a pure compound Pentandraone $(11.4 \mathrm{mg})$. The results of the extraction along with the abbreviations used for methanolic extracts are given in Table 4.

Physical and spectroscopical data of the isolated compound Pentandraone

Amorphous solid (11.4 mg), UV (MeOD) $\lambda_{\max } \mathrm{nm}(\log \varepsilon)$ $=275(0.17) \mathrm{IR} v_{\max }(\mathrm{KBR}) \mathrm{cm}^{-1}=2957,2926,2855,1729$, $1282{ }^{1} \mathrm{H}-\mathrm{NMR}(\mathrm{MeOD}, 300 \mathrm{MHz}): \delta 7.59(1 \mathrm{H}, \mathrm{d}, \mathrm{J}=2.7 \mathrm{~Hz}$, $\mathrm{H}-1), 7.60(1 \mathrm{H}, \mathrm{dd}, \mathrm{J}=3.0,6.0 \mathrm{~Hz}, \mathrm{H}-2), 7.62(1 \mathrm{H}, \mathrm{dd}, \mathrm{J}=$ 1.2, 3.1, Hz, H-3), 7.61(1H, d, J = 3.3 Hz, H-4) $2.27(1 \mathrm{H}, \mathrm{t}, \mathrm{J}$
$=7.2, \mathrm{~Hz}, \mathrm{H}-9), 1.55$ (2H, dt, J = 9.0, 8.1 Hz, H-11), 1.58 $(2 \mathrm{H}, \mathrm{t}, \mathrm{J}=8.2 \mathrm{~Hz}, \mathrm{H}-12), 1.60(2 \mathrm{H}, \mathrm{dt}, \mathrm{J}=6.9,8.3 \mathrm{~Hz}, \mathrm{H}-$ 15), $1.63(2 \mathrm{H}, \mathrm{dt}, \mathrm{J}=6.8,4.2, \mathrm{~Hz}, \mathrm{H}-16), 2.32$ (2H, q, J = 7.5 $\mathrm{Hz}, \mathrm{H}-21), 0.97$ (3H, t, J = 0.9, Hz, H-22), 4.20 (1H, dt, J = 5.4, $6.6 \mathrm{~Hz}, \mathrm{H}-23), 2.25$ (2H, dd, J = 5.9, $6.2 \mathrm{~Hz}, \mathrm{H}-24), 4.16$ $(1 \mathrm{H}, \mathrm{q}, \mathrm{J}=12.0 \mathrm{~Hz}, \mathrm{H}-25), 3.89$ (2H, q, J = 1.5 Hz, H-27), $0.86(3 \mathrm{H}, \mathrm{t}, \mathrm{J}=2.8 \mathrm{~Hz}, \mathrm{H}-28){ }^{13} \mathrm{C}-\mathrm{NMR}$ (MeOD,75.4MHz): $\delta 129.3$ (C-1), 129.4(C-2), 129.6 (C-3), 129.8 (C-4), 132.5 (C5), 129.4 (C-6), 132.3 (C-7), 35.3 (C-8), 48.7 (C-9), 132.5 (C-10), 26.4 (C-11), 30.1 (C-12), 132.0 (C-13), 132.4 (C-14), 30.4 (C-15), 30.6 (C-16), 136.8 (C-17), 14.0 (C-18), 25.5 (C19), 130.3 (C-20), 20.1 (C-21), 26.2 (C-22), 68.5 (C-23), 35.1(C-24), 70.1 (C-25), 169.3 (C-26), 66.6 (C-27), 11.4 (C28) EI-MS $m / z$ (rel.int) 57.1, 91.1, 206.1, 293.1, 418. HR-EIMS $m / z: 418.2[\mathrm{M}+\mathrm{H}]^{+}$Calculated for $\mathrm{C}_{28} \mathrm{H}_{34} \mathrm{O}_{3}: 418$ ).

Table 1: Results of the extraction of the plants Zaleya pentandra

\begin{tabular}{|c|c|c|c|c|}
\hline Plant Name & Part Used & Solvent & Weight of Extract (g) & Abbreviation for the extracts \\
\hline Zaleya pentandra & Aerial parts $(1000 \mathrm{~g})$ & Methanol & 35 & ZPM \\
\hline
\end{tabular}

Table 2: ${ }^{13} \mathrm{C}(75.4 \mathrm{MHz})$ and ${ }^{1} \mathrm{H}-\mathrm{NMR}(300 \mathrm{MHz})$ Spectral Data of Compound "Pentandraone"

\begin{tabular}{|c|c|c|c|c|}
\hline Carbon No. & Multiplicity DEPT & 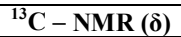 & H- NMR (ס) & J. Value \\
\hline $\mathrm{C}-1$ & $\mathrm{CH}$ & 129.3 & $7.59 \mathrm{~d}$ & $\left(\mathrm{~J}=2.7, \mathrm{~Hz} z^{\prime} \mathrm{H}-1\right)$ \\
\hline $\mathrm{C}-2$ & $\mathrm{CH}$ & 129.4 & $7.60 \mathrm{dd}$ & $(\mathrm{J}=3.0,6.0 \mathrm{~Hz}, \mathrm{H}-2)$ \\
\hline $\mathrm{C}-3$ & $\mathrm{CH}$ & 129.6 & $7.62 \mathrm{dd}$ & $(\mathrm{J}=1.2,3.1, \mathrm{~Hz}, \mathrm{H}-3)$ \\
\hline $\mathrm{C}-4$ & $\mathrm{CH}$ & 129.8 & $7.61 \mathrm{~d}$ & $(\mathrm{~J}=3.3, \mathrm{~Hz}, \mathrm{H}-4)$ \\
\hline $\mathrm{C}-5$ & $\mathrm{C}$ & 132.5 & - & - \\
\hline $\mathrm{C}-6$ & $\mathrm{C}$ & 129.4 & - & - \\
\hline $\mathrm{C}-7$ & $\mathrm{CH}$ & 132.3 & $5.31 \mathrm{~s}$ & $\mathrm{~J}=(1 \mathrm{H}, \mathrm{s}, \mathrm{H}-7)$ \\
\hline $\mathrm{C}-8$ & $\mathrm{C}$ & 35.3 & - & - \\
\hline $\mathrm{C}-9$ & $\mathrm{CH}$ & 48.7 & $2.27 \mathrm{t}$ & $(\mathrm{J}=7.2, \mathrm{~Hz}, \mathrm{H}-9)$ \\
\hline $\mathrm{C}-10$ & $\mathrm{C}$ & 132.5 & - & - \\
\hline $\mathrm{C}-11$ & $\mathrm{CH}_{2}$ & 26.4 & $1.55 \mathrm{dt}$ & $(\mathrm{J}=9.0,8.1, \mathrm{~Hz} \mathrm{H}-11)$ \\
\hline $\mathrm{C}-12$ & $\mathrm{CH}_{2}$ & 30.1 & $1.58 \mathrm{t}$ & $(\mathrm{J}=8.2, \mathrm{~Hz}, \mathrm{H}-12)$ \\
\hline $\mathrm{C}-13$ & $\mathrm{C}$ & 132.0 & - & - \\
\hline $\mathrm{C}-14$ & $\mathrm{C}$ & 132.4 & - & - \\
\hline $\mathrm{C}-15$ & $\mathrm{CH}_{2}$ & 30.4 & $1.60 \mathrm{dt}$ & $(\mathrm{J}=6.9 \mathrm{~Hz}, 8.3, \mathrm{H}-15)$ \\
\hline $\mathrm{C}-16$ & $\mathrm{CH}_{2}$ & 30.6 & $1.63 \mathrm{dt}$ & $(\mathrm{J}=6.8,4.2 \mathrm{~Hz}, \mathrm{H}-16)$ \\
\hline $\mathrm{C}-17$ & $\mathrm{C}$ & 136.8 & - & - \\
\hline $\mathrm{C}-18$ & $\mathrm{CH}_{3}$ & 14.0 & $0.89 \mathrm{~s}$ & - \\
\hline $\mathrm{C}-19$ & $\mathrm{CH}_{3}$ & 25.5 & $0.90 \mathrm{~s}$ & - \\
\hline $\mathrm{C}-20$ & $\mathrm{C}$ & 130.3 & - & - \\
\hline $\mathrm{C}-21$ & $\mathrm{CH}_{2}$ & 20.1 & $2.32 \mathrm{q}$ & $(\mathrm{J}=7.5 \mathrm{~Hz}, \mathrm{H}-21)$ \\
\hline $\mathrm{C}-22$ & $\mathrm{CH}_{3}$ & 26.2 & $0.97 \mathrm{t}$ & $(\mathrm{J}=0.9, \mathrm{~Hz}, \mathrm{H}-22)$ \\
\hline $\mathrm{C}-23$ & $\mathrm{CH}$ & 68.5 & $4.20 \mathrm{dt}$ & $(\mathrm{J}=5.4,6.6 \mathrm{~Hz}, \mathrm{H}-23)$ \\
\hline $\mathrm{C}-24$ & $\mathrm{CH}_{2}$ & 35.1 & $2.25 \mathrm{dd}$ & $(\mathrm{J}=5.9,6.2 \mathrm{~Hz}, \mathrm{H}-24)$ \\
\hline $\mathrm{C}-25$ & $\mathrm{CH}$ & 70.1 & $4.16 \mathrm{q}$ & $(\mathrm{J}=12.0 \mathrm{~Hz}, \mathrm{H}-25)$ \\
\hline $\mathrm{C}-26$ & $\mathrm{C}$ & 169.3 & - & - \\
\hline $\mathrm{C}-27$ & $\mathrm{CH}_{2}$ & 66.6 & $3.89 \mathrm{q}$ & $(\mathrm{J}=1.5, \mathrm{~Hz}, \mathrm{H}-27)$ \\
\hline $\mathrm{C}-28$ & $\mathrm{CH}_{3}$ & 11.4 & $0.86 \mathrm{t}$ & $(\mathrm{J}=2.8, \mathrm{~Hz}, \mathrm{H}-28)$ \\
\hline
\end{tabular}<smiles>CCOC1CC(C(CC)=C2CCC3=C2CCC2c4ccccc4C(C)=CC32C)OC1=O</smiles>

Figure 1: Structure of compound (Pentandraone: $\mathrm{C}_{28} \mathrm{H}_{34} \mathrm{O}_{3}: 418$ ) 


\section{RESULTS AND DISCUSSION}

The isolated compound was obtained as amorphous solid from the methanolic extract of Zaleya Pentandra. The IR spectrum of compound, the absorption bands at $1726 \mathrm{~cm}^{-1}$ is due to carbonyl group function. The stretching was observed at $2855 \mathrm{~cm}^{-1}$ due to $\mathrm{Sp}^{3} \mathrm{C}-\mathrm{H}$ and at $2926 \mathrm{~cm}^{-1}$ indicated the presence of $\mathrm{Sp}^{2} \mathrm{C}-\mathrm{H}$. From the study of mass spectrum, the molecular formula was calculated as $\mathrm{C}_{28} \mathrm{H}_{34} \mathrm{O}_{3}$ through HREIMS showing molecular ion peak $[\mathrm{M}+\mathrm{H}]^{+}$at $\mathrm{m} / z 418$ (calculated for $\mathrm{C}_{28} \mathrm{H}_{34} \mathrm{O}_{3}$. 418). The UV spectrum in $\mathrm{MeOH}$ displayed $\lambda_{\max }$ at 275 which showed the presence of conjugation and unsaturation system in molecule. The ${ }^{1} \mathrm{H}-$ NMR spectrum of compound has displayed a peak for aromatic proton at $\delta 7.59(1 \mathrm{H}, \mathrm{d}, \mathrm{J}=2.7 \mathrm{~Hz}), 7.60(1 \mathrm{H}, \mathrm{dd}, \mathrm{J}$ $=3.0,6.0 \mathrm{~Hz}), 7.62(1 \mathrm{H}, \mathrm{dd}, \mathrm{J}=1.2,3.1 \mathrm{~Hz}), 7.61(1 \mathrm{H}, \mathrm{d}, \mathrm{J}=$ $3.3 \mathrm{~Hz})$, hydrogen belonging to lactone appeared at $\delta 4.20$ $(1 \mathrm{H}, \mathrm{dt}, \mathrm{J}=5.4,6.6 \mathrm{~Hz}), \delta 4.16(1 \mathrm{H}, \mathrm{q}, \mathrm{J}=12.0 \mathrm{~Hz})$, a singlet of alkene proton appeared at $\delta 5.31(1 \mathrm{H}, \mathrm{s})$, aliphatic proton also appeared at $\delta 1.18$. The methyl protons gave signal at $\delta 0.86(3 \mathrm{H}, \mathrm{t}, \mathrm{J}=2.8 \mathrm{~Hz}), \delta 0.89(3 \mathrm{H}, \mathrm{s}), 0.90(3 \mathrm{H}$, s) $\delta 0.97(3 \mathrm{H}, \mathrm{t}, \mathrm{J}=0.9 \mathrm{~Hz})$. The ${ }^{13} \mathrm{C}-\mathrm{NMR}$ spectrum of the compound revealed twenty eight carbon atoms consisting of four methyl, eight methines, seven methylenes, 9 quaternary carbon items. The downfield signal at $\delta 129.4-132.5$ showed the presence of aromatic carbon. The downfield signals found at $\delta 169.3$ clearly indicated the presence of $\mathrm{C}=0$ carbon. The presence of the lacton carbons was indicated at $\delta 70.1$. The values of ${ }^{13} \mathrm{C}$ - NMR (75.4 MHz) and ${ }^{1} \mathrm{H}-\mathrm{NMR}$ (300 MHz) spectral data of compound "Pentandraone" are shown as follows. (Table 2) On the basis of spectral data, the structure of compound was established as [3- ethoxy - dihydro-5((1E)-1-(11, 12, 15, 16 -tetrahydro-6, 8-dimethyl-8Hcyclopenta (a) phenanthren- $17(9 \mathrm{H})$ - ylidene) propyl) furan $-2(3 \mathrm{H})-$ one] and it was found to be a novel natural product. It was named on the basis of the species as pentandraone. (Figure 1)

\section{ACKNOWLEDGEMENT}

The project was supported by B. Z. University Multan, Pakistan. We also wish to acknowledge the technical support of H.E.J. Research Institute of Chemistry, International Center for Chemical and Biological Sciences (ICCBS), University of Karachi-75270, Karachi, Pakistan.

\section{REFERENCES}

1. Nasir E and Ali SI. Flora of Pakistan. Shamim Printing Press Karachi, Pakistan; 1986. p. 1, 88, 99, 101.

2. Singaravel Sengottuvelu, Duraisamy Srinivasan, Rasilingam Duraisami, Jothivel Nandhakumar, Mani Vasudevan, Thangavel Sivakumar. Hepatoprotective activity of Trianthema decandra on carbon tetrachloride induced hepatotoxicity in rats. International Journal of Green Pharmacy 2008; 122-125.

3. Meenakshi Periasamy, Bhuvaneshwari Rajendran, Ahalliya RM, Thirumoorthi Lakshmanan, Chinna GD, Janardhanan Jiji, Kanniappan GV. Antidiabetic activity of ethanolic extract of Zaleya decandra in alloxan-induced diabetic rats. Applied biochemistry and biotechnology
2010; 162(4): 1153-1159. http://dx.doi.org/10.1007/s12010-009-8871-x PMid: 19957208

4. Balamurugan G, Muthusamy P. Observation of the hepatoprotective and antioxidant activities of Trianthema decandra Linn. (Vallai Sharunnai) roots on carbon tetrachloride-treated rats. Bangladesh Journal of Pharmacology 2008; 3: 83-89. http://dx.doi.org/10.3329/bjp.v3i2.890

5. Radfar M, Sudarshana M, Kavitha U, Satish S, Niranjan MH. Evaluation of antibacterial and antifungal activity of root and root callus extracts of Zaleya decandra L. African Journal of Biotechnology 2012; 11(2): 510515.

6. Jaswanth A, Jagannathan K, Robert SH, Loganathan V, Manimaran S, Ruckmani K. Antibacterial Activity of root extract of Trianthema decandra. Ancient science of life 2002; 21: 158-159.

7. Geethalakshmi R, Sarada DVL, Ramasamy K. Trianthema decandra L: A review on its phytochemical and pharmacological profile. International journal of engineering, science and technology 2010;2(5): 976-979.

8. Banu GS, Kumar G, Murugesan AG. Ethanolic leaves extract of Trianthema portulacastrum L. Ameliorates aflatoxin b1 induced hepatic damage in rats. Indian J Clin Biochem 2009; 24: 250-6. http://dx.doi. org/10.1007/s12291-009-0047-5 PMid:23105844 PMCid:PMC3453304

9. Bhattacharya S, Chatterjee M. Protective role of Trianthema portulacastrum against diethylnitrosamine induced experimental hepatocarcinogenesis. Cancer Lett 1998; 129: 7-13. http://dx.doi.org /10.1016/S0304-3835(98)00085-8

10. Anreddy RN, Porika M, Yellu NR, Devsrakonda RK. Hypoglycemic and hypolipidemic activities of Trianthema portulacastrum Linn. Plant in normal and alloxan induced diabetic rats. Int J Pharmacol 2010; 6(2): 129-33. http://dx.doi.org/10.3923/ijp.2010.129.133

11. Mahmood Adeel, Mahmood Aqeel, Shaheen Hamayun, Qureshi RA, Sangi Yasmin, and Gilani SA. Ethno medicinal survey of plants from district Bhimber Azad Jammu and Kasmir, Pakistan. Journal of Medicinal Plants Research 2011; 5: 2348-2360.

12. Karim M, Ashraf N, Kalam A, Jahan N, Jafri MA and Ahmad G. Effects of Biskhapra (Trianthema portulacastrum Linn.) leaves extract in adriamycin induced nephrotic syndrome. International Journal of Green Pharmacy 2011; 5(4): 329. http://dx.doi.org/10.4103/0973-8258.94357

13. Shivhare MK, Singour PK, Chaurasiya PK and Pawar RS. Trianthema portulacastrum Linn. (Bishkhapra). Pharmacogn Rev 2012; 6(12): 132140. PMid:23055639 PMCid:PMC3459455

14. Banerji A, Chintalwar GJ, Joshi NK, Chadha MS. Isolation of ecdysterone from Indian plants. Phytochemistry 1971; 10: 2225-6. http://dx.doi.org/10.1016/S0031-9422(00)97227-3

15. Kokpol U, Wannachet Isara N, Tip Pyang S, Chavasiri W, Veerachato G, Simpson J, and Weavers RT. A C methylflavone from Trianthema portulacastrum. Phytochemistry 1997; 44(4): 719-722. http://dx.doi. org/10.1016/S0031-9422(96)00560-2

16. Ahmad J, Farooqui AH and Ahmad S. Trianthema portulacastrum L., an Herbal Drug for the Cure of Edema. Journal of Herbs, Spices and Medicinal Plants 2000; 7(2): 65-70. http://dx.doi.org/10.1300 /J044v07n02_07

17. Seifu T. Ethno botanical and ethno pharmaceutical studies on medicinal plants of Chifra District, Afar Region, North Eastern Ethiopia, Doctoral dissertation, Addis Ababa University; 2004.

18. Hameed M, Ashraf M, Al Quriany F, Nawaz T, Ahmad MSA, Younis A and Naz N. Medicinal flora of the Cholistan desert: a review. Pakistan journal of Botany 2011; 43: 39-50.

19. Qasim M, Gulzar S and Khan MA. Halophytes as medicinal plants. In NAM Meeting in Denizli, Turkey; 2011.

Cite this article as:

Samina Afzal, Bashir Ahmad Chaudhary, Muhammad Uzair, Khurram Afzal, Tasveer Zahra Bokhari. Isolation of pentandraone from methanolic extract of aerial part of Zaleya pentandra. Int. Res. J. Pharm. 2013; 4(9):2123 http://dx.doi.org/10.7897/2230-8407.041006 